\title{
TEACHING WRITING DESCRIPTIVE TEXTS TO THE EIGHTH YEAR STUDENTS: "PUT YOURSELF IN THE PICTURE” ACTIVITY
}

\author{
Krisdian Eka Permatasari \\ Email:krisdianekapsari@gmail.com \\ Universitas Negeri Surabaya
}

\begin{abstract}
Writing is considered as a complicated and difficult skill to be mastered by the students. Several difficulties are found in learning of descriptive writing. Dealing with the case, the research questions are proposed as follows: (1) How is "Put Yourself in the Picture" activity implemented by the teacher in teaching descriptive texts? and (2) How are the results of the students in writing descriptive texts in the aspects of grammar, vocabulary, content and organization through the implementation of "Put Yourself in the Picture" activity? This research is qualitative design in which the researcher acted as the observer to collect information as the evidences in the writing class to find the teacher's and students' activities in implementing "Put Yourself in the Picture" activity in the three stages of teaching learning process in writing descriptive texts. The results of the research showed that the teacher and the students implemented "Put Yourself in the Picture" activity in some of the these activities, as follows: (1) introducing the essay topic; (2) listing the words or phrases relating to the topic; (3) Making sentences based on the listed ideas; (4) identifying the generic structures and language features of descriptive text; (5) Writing the descriptive text; (6) Making groups and giving feedbacks of the writing' results; (7) Editing and re writing the final drafts. Besides, the students' learning writing progresses are described into five categories. They are (1) very good student's score category; (2) good student's score category; (3) fair student's score category; (4) poor student's score category; and (5) very poor student' score category. These criteria are based on the students' writing results analyzed in the aspects of grammar, vocabulary, content, and organization.
\end{abstract}

Key Words: Put yourself in the picture activity, teaching writing process of descriptive texts

\section{INTRODUCTION}

Writing is one of the primary skills taught in teaching and learning activities of English classroom. Writing is important to convey 
ideas, give instructions, share and preserve knowledge and so on. Wingersky et al. (1999: 4) argue that when we write, we have the opportunity to organize our thoughts and words until we are happy with the finished product. It means that writing involves of communicating messages in the written form. Moreover, Harmer (1998: 79) points out that the reasons for teaching writing to the students of English as a foreign language are for reinforcement, language development, learning style, and most importantly as a basic skill. Because of the reason, the teachers should teach all the English language skills, including writing, to the students in achieving the specialized skill.

Writing is a tool in which students can find a way to write down ideas and explore thought. As what Ploeger (2000: xiii) states, writing is the way we express our ideas fully, clearly, in an organized and effective manner. It is a way of discovering what we know and feel about something and communicating that knowledge to our audiences. Dealing with learning activity, Brown (2001: 81) also points out that there are two ways for motivating learners in writing activity. Those two ways are "creating a pleasant, relaxed atmosphere in the classroom" and "making the language classes interesting." It can be assumed that writing is an enjoyable part of the foreign language lesson, as it provides students a space to express their personalities.

However, writing is considered as a complex skill and difficult to be mastered by the students. Writing is regarded as the most difficult skill for foreign language learners to master because it involves several components which need to be considered while the learners are writing, such as content, organization, vocabulary, language use and punctuation (Brown, 2004: 244-245). Besides, Heaton (1991: 135) also points out that the writing skills are complex and sometimes difficult to teach, requiring mastery not only of grammatical and rhetorical devices but also of conceptual and judgmental elements. In addition, he also describes five general components which are necessary for good writing:

1. language use: the ability to write correct and appropriate sentences; 
2. mechanical skills: the ability to use correctly those conventions peculiar to the written language- e.g. punctuation, spelling;

3. treatment of content: the ability to think creatively and develop thoughts, excluding all irrelevant information;

4. stylistic skill: the ability to manipulate sentences and paragraphs, and use language effectively;

5. judgment skills: the ability to write in an appropriate manner for a particular purpose with a particular audience in mind, together with an ability to select, organize, and order relevant information.

Further, Lylon and Heasly (in Sudarsono, 2001: 65) state that writing is a complex process and competent writing is frequently accepted as being the last language skill to be acquired. From the explanation above, it can be concluded that writing well is not easy to do because it has the complex process in its implementation.

Prior to this research, a preliminary study was done with the eighth grade English teacher of SMPN 1 Panceng, Gresik on March, 04th 2015 by the researcher. Informal talks with the English teacher were intended to know firsthand information concerning the English teaching and learning process in that school. The interview guide in the form of a list of questions was used during the process of interview.

The teacher said that most of the eighth year students had trouble getting started with writing or the finding the idea about what to write first in writing descriptive texts. They might not be sure of what they want to write to develop the ideas in determining the content of the text. This finding was revealed by some research concerning the students' writing ability at Junior High School was still low. Sundari (2002:24) conducted a study intended to improve the second year students' writing skill through pictures. Her preliminary study revealed that the students faced difficulty in writing English especially in expressing their idea. In addition, Sulistiani (2007) conducted a research aimed to improve the students' writing skill of the first year students. Referring to her preliminary study, she found that the students had the difficulties in finding the idea to start writing. From the findings described above, it can be concluded that there were some problems found in the teaching of writing. 
In relation to the use of media, the teacher also used picture as the media in teaching writing process. However, this media was only used as the example when the teacher explained the genre of the text in front of the class. It was not used to help them develop their ideas in writing the text. The strategy used by the teacher was not interesting. As a result, the students were unable to act well in learning writing and most of the students' writing scores were below the required minimum score of the school for the English subject. The minimum requirement standard score of English at SMPN 1 Panceng, Gresik was 65.

Based on the problems identified, it is essential to select a suitable strategy in teaching writing. Brown (2001: 340) suggests that the teacher has a role as a facilitator who offers guidance to the students in creating an interesting and motivating lesson. Thus, the teachers must be creative in selecting and preparing instructional media.

However, the teachers should follow some considerations in applying instructional media in order not to face many difficulties in the teachers' activities during teaching and learning process in the classroom. The instructional media should be easy to be prepared and organized. For the reason, pictures can be used as the instructional aids in teaching writing. Pictures are used because they are easy to prepare, easy to organize, and interesting (Wright, 1992: 3). Further, he explains that pictures play a role in motivating the students to pay attention and want to take a part.

From the point of view of pictures, the strategy that can be recommended in teaching writing was the use of "Put Yourself in the Picture" activity. The media used was picture. This activity is adapted from Lindstromberg (2004: 132). In this activity, the students were asked to imagine that they were no longer in the classroom but in the picture. They could stand, sit, lay or whatever they want to imagine in it. They could be near, but they must be visible.

"Put Yourself in the Picture" activity helped the students to express their imagination that they were involved in the picture indirectly. Then, the students would think freely the vocabulary items around their positions by describing them into a short text. It means 
that the picture itself had a purpose for the students to help them develop their ideas in mind by reading it. This purpose deals with Calhoun's explanation (1999: 68) which points out that pictures are easily understandable and can help our students to be immediately and personally successful in visually reading the picture, shaking words out of the picture and generating the word list.

Research studies that involve the use of "Put Yourself in the Picture" activity in teaching and learning writing had been conducted by some researchers. A study in implementing "Put Yourself in the Picture" strategy was conducted by Wiyanto in 2011. His study was aimed to know the effect of this strategy to improve the students' ability of the eighth grade of SMPN 1 Jombang in writing recount text. He conducted two cycles. The research findings showed that the average score of the students was 69 in the second cycle and it was greater than the minimum requirement standard score (65). It showed that this strategy was the effective way to improve students' ability in writing recount text at SMPN 1 Jombang.

Wati (2008) employed "Put Yourself in the Picture" strategy in teaching descriptive text of MTs. Muhammadiyah 1 Jombang. The subjects of the study were the second year students. The problem of her research was the strategies that the teacher used to teach writing was not interesting. The teacher only assigned them to write paragraphs without giving any models of good paragraph writing. The teacher also monotonously let them write the paragraph alone without giving any feasible example of paragraph writing strategies. Hence, the strategies applied by the English teacher seemed to be less effective since the teacher did not apply some interesting activities in the classroom to develop the students' skill in paragraph writing.

Through the implementation of "Put Yourself in the Picture"activity by using classroom action research in two cycles, she found that the students' results in writing descriptive text got the significant improvement from the first cycle to the second cycle. The instruments that she used were the students' scores, the observation checklist, field notes, and questionnaires.

The previous studies above highlighted the use of pictures to improve the students' writing ability. This research also drew attention 
to the use of pictures in teaching writing. Kind of text used in this research was descriptive text. The genre of the text was different with the one that Wiyanto used, recount text. Nevertheless, the genre of the text of this research was same with Rochmah Wati used, descriptive text.

Then, dealing with the root of the problem, this research had the same problem with Rochmah Wati' research. Inappropriate teaching and learning strategy was the main cause. The strategy used by teacher was not interesting. What makes this research different from two previous studies above was the research design. This research used a qualitative design and those two previous studies used classroom action research. By considering the explanation above, Put Yourself in the Picture activity was appropriate to be undertaken as an alternative way to investigate how it was understood and implemented by the teachers and students in the classroom.

\section{METHOD}

This research was designed as a qualitative design. It was carried out to obtain the description of the implementation of "Put Yourself in the Picture" activity in teaching writing descriptive texts. According to Creswell (2012: 16), the characteristic of qualitative research is analyzing the data for description and themes using text analysis and interpreting the larger meaning of the findings. Further, he states that the researcher can analyze words or pictures to describe the central phenomenon under study. It can be said that in qualitative research, the data can be analyzed and described by using words, sentences, or pictures as the representations in finding out the results of the research.

Furthermore, Yin (2011: 6) adds that qualitative research enables researcher to conduct in depth studies of broad topic. It means that this kind of research conducts the studies of related problem in depth. In this research, the researcher observed deeply on teacher and students' activities in the classroom. The teacher and students' activities in teaching of writing in the classroom were described in details by using "Put Yourself in the Picture" activity. 
The subjects and setting of this research were the teacher and students of class VIII-B of SMPN 1 Panceng, Gresik. There were four classes of the eighth grade students of SMPN 1 Panceng, Gresik. Class B was chosen because it was class where the students had experienced in the use of media of pictures to write descriptive texts. This class had 20 students. Further, the teacher was also chosen because she had already implemented pictures as the media in teaching writing descriptive texts and she was the English teacher of the eighth year of this school.

The data of this research was the teacher and students' activities in applying "Put Yourself in the Picture" activity in the process of teaching writing process in the classroom and the results of the students' writings through the implementation of this activity. The data was in the form of the teacher's utterances and students'responses in form of note taking. The data was used to answer research questions. The source of data was the teaching writing process of implementing "Put Yourself in the Picture" activity in the classroom. The teaching writing process was observed from the beginning until the end of lesson.

The aspect of qualitative data collection is to identify the types of data that will address to research questions (Creswell, 2012: 212). Thus, it is important to become familiar with the questions and topics and to review them prior to deciding upon the types of qualitative data that will be collected. In this research, the qualitative forms of data collected were observation and documents.

\section{Observation}

Observation is the process of gathering open-ended, firsthand information by observing people and places at a research site (Creswell, 2012: 213). This kind of data collection technique was used to answer the first research question. The observation was taken to collect data related to the teacher's and students' activities in applying "Put Yourself in the Picture" activity in teaching and learning writing of descriptive text. To be a well-accepted form of qualitative data collection, role of a nonparticipant observer was applied in this research. 
A nonparticipant observer is an observer who visits a site and records notes without becoming involved in the activities of the participants. The nonparticipant observer is an "outsider" who sits on the periphery or some advantageous place (e.g., the back of the classroom) to watch and record the phenomenon under study (Creswell, 2012: 214).

While applying the non-participant observer, the researcher did not involve in teaching and learning process. She only had seat on the back classroom to watch and record the phenomenon in the class. In this case, the activities happened were observed during the learning processes by taking notes of the important information. Moreover, the classroom's condition like the interaction between teacher and student or student with students, and the students' activities in teaching writing process were also observed.

Dealing with recording data, this process involved recording information to anticipate potential problems in data collection. In this research, an observational protocol in the form of checklist or the observation checklist was used in prewriting, writing, and post writing stages to observe the teaching writing process of descriptive text in the classroom. Creswell (2012: 225) points out that an observational protocol is a form designed by the researcher before data collection that is used for taking fieldnotes during an observation.

The checklist was used to know the application of "Put Yourself in the Picture" activity in the three stages by giving a mark of provided qualification (see Appendix 3). The observation itself was conducted in six meetings. Each of three meetings was included in the stages of writing processes. They were prewriting, writing and post writing. The writing processes were implemented on 9, 11, 16, 18, 23, 25 September 2014.

In addition, the data recorded during an observation is called fieldnotes. Fieldnotes are text (words) recorded by the researcher during an observation in a qualitative study (Creswell, 2012: 216). Field notes was used to record the factual data which did not exist in observation checklist such as the phenomena and essential features occurred in the classroom activities. The examples of the observation checklist and fieldnotes were presented in Appendix 3 and 4. 


\section{Documents}

A valuable source of information in qualitative research can be documents. Creswell (2012: 23) states that documents consist of public and private records that qualitative researchers obtain about a site or participants in a study. He further explains that the examples of public documents are minutes from meetings, official memos, records in the public domain, and archival material in libraries. Private documents consist of personal journals and diaries, letters, personal notes, and jottings individuals write to themselves.

In this research, the results of the students' writing in the form of scores were regarded as the documents and used to answer the second research question. Then, the students' learning writing progresses were described into five categories. They were (1) very good student's score category; (2) good student's score category; (3) fair student's score category; (4) poor student's score category; and (5) very poor student' score category. These criteria were based on the students' writing results evaluated in the aspects of grammar, vocabulary, content, and organization. The criteria of evaluation used Analytical Scoring Rubric adapted from Cohen (1994: 328-329).

Data analysis is the process of making sense out of the data. Making sense out of data involves consolidating, reducing, and interpreting what people have said and what the researcher has seen and read (Merriam, 2009: 175). It means that this process constitutes the finding of the research. In addition, Creswell (2012: 237) argues that qualitative research is "interpretive" research, in which we make a personal assessment as to a description that fits the situation or themes that capture the major categories of information. It means that the interpretation that we made was different from the interpretation that someone else and brought the perspective to our interpretation. Afterwards, the data analysis technique was analyzed in three procedures that were suggested by Miles et al. (2014: 31). They were data condensation, data display, and verification and conclusion drawing. 


\section{Data Condensation}

Data condensation refers to the process of selecting, focusing, simplifying, abstracting, and/or transforming the data that appear in the full corpus (body) of written-up field notes, interview transcripts, documents, and other empirical materials (Miles, 2014: 31). At first, the data resulted from observations and documents of the teacher' and students' activities in applying "Put Yourself in the Picture" activity were selected to be associated to the teaching writing procedures.

Then, the data was categorized to fit how was "Put Yourself in the Picture" activity implemented by the teacher in teaching writing process of descriptive text (first research question) and how were the results of the students in writing descriptive text through the implementation of "Put Yourself in the Picture" activity (second research question). After that, the data was interpreted by comparing the used strategy to fit the teaching and learning procedures. At last, the first and second questions were analyzed to relate with the procedures of "Put Yourself in the Picture" activity in the theories.

The further process of analyzing text (or images) in qualitative research began when we coded the data. Coding is the process of segmenting and labeling text to form descriptions and broad themes in the data (Creswell, 2012: 243). The resulted data in the form of words, phrases, or sentences of interaction between the teacher and the students used codes as seen below.

\begin{tabular}{|l|l|}
\hline Codes & Meaning \\
\hline T & Teacher \\
S1 & Student, using number (S1, S2, \\
WS & S3,S4,S5) \\
$\#$ & Whole Students \\
$\# \#$ & One second (silence) \\
$\# \# \#$ & Two seconds (start responding) \\
$*$ & Three seconds (pause) \\
Italic & The speaker began to interrupt \\
& Indonesian \\
\hline
\end{tabular}




\section{Data Display}

The second major flow of analysis activity was data display. A display is an organized, compressed assembly of information that allows conclusion drawing and action (Miles et al., 2014: 31). They also argue that designing displays, deciding on the rows and columns of a matrix for qualitative data and deciding which data, in which form, should be entered in the cells, are analytic activities. The displayed data were described and connected to the stages of "Put Yourself in the Picture" activity in pre writing, writing, and post writing stages in the table, as follows.

\begin{tabular}{|l|l|l|}
\hline Stages & Activities & Data Condensation \\
\hline Pre & $\begin{array}{l}\text { I. Introducing the essay } \\
\text { topic }\end{array}$ & $\begin{array}{l}\text { T: Can you mention what are } \\
\text { your favorite places on holiday } \\
\text { based on your pictures? } \\
\text { S1: WBL, Mom! } \\
\text { S5: Maharani Zoo! } \\
\text { S13: Dalegan Beach Mom! } \\
\text { T: Ok, Good! Can you guess } \\
\text { what the topic of the lesson is } \\
\text { today? } \\
\text { S13, S17: Favorite places, Mom! } \\
\text { S4: Favorite places on holiday! } \\
\text { T: Yes, all of you are right. } \\
\text { or phrases }\end{array}$ \\
& $\begin{array}{l}\text { Categorizing the words } \\
\text { S13: Mom, in the question of } \\
\text { what you can see in the picture, } \\
\text { may I answer the word 'people'? } \\
\text { T: Yes, of course! You can } \\
\text { write many words based on your } \\
\text { imagination. It depends on the } \\
\text { location you have chosen. It can } \\
\text { be beach, zoo, park, and many } \\
\text { other places. If you choose } \\
\text { beach, you write what you are } \\
\text { seeing and people are doing } \\
\text { there. Any other questions? } \\
\text { S6: Mom, in the second }\end{array}$ \\
\hline
\end{tabular}




\begin{tabular}{|c|c|}
\hline $\begin{array}{l}\text { 3. Developing the listing } \\
\text { ideas into sentences }\end{array}$ & 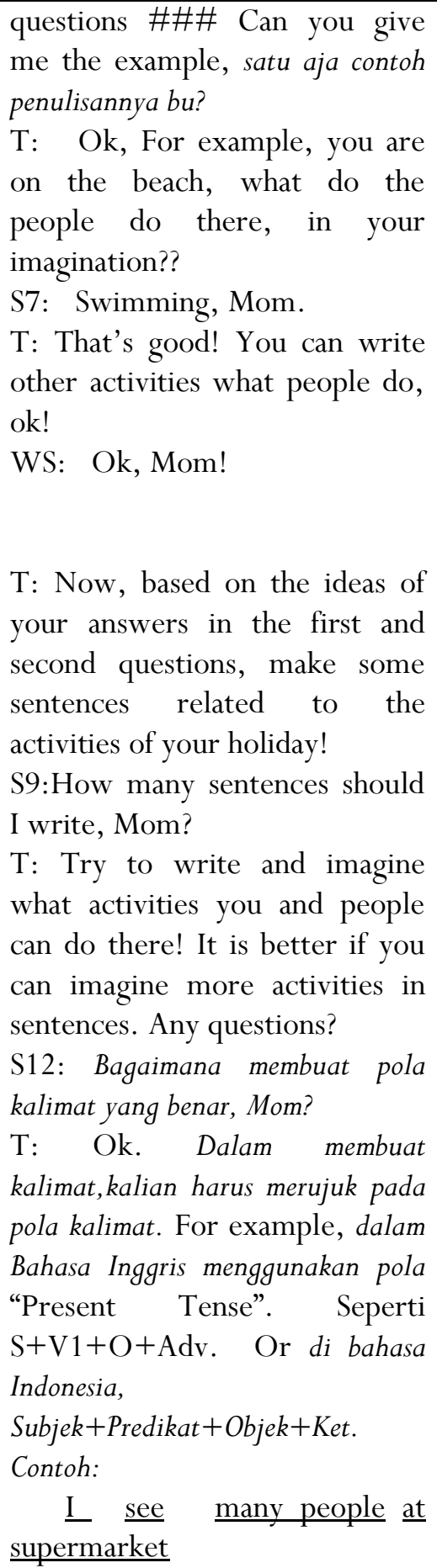 \\
\hline
\end{tabular}




\begin{tabular}{|c|c|c|}
\hline & & $\begin{array}{l}\quad \mathrm{S} P \quad \mathrm{O} \quad \text { Adv of } \\
\text { place } \\
\text { S12: Ok, Mom. }\end{array}$ \\
\hline \multirow[t]{2}{*}{ Writing } & $\begin{array}{l}\text { 4. Identifying the generic } \\
\text { structures and language } \\
\text { features of descriptive text }\end{array}$ & $\begin{array}{l}\text { T: Ok. If you want to describe a } \\
\text { particular person, place, or } \\
\text { thing, do you know what kind of } \\
\text { text should you write? } \\
\text { S17, S4: Descriptive Text, } \\
\text { Mom! } \\
\text { T: Good! Now, do you still } \\
\text { remember what are the generic } \\
\text { structures and language features } \\
\text { of descriptive text? } \\
\text { S7: Identification and \# apa lagi } \\
\text { ya..lupa bu.. } \\
\text { SI3: Description bu, pakai present } \\
\text { tense! } \\
\text { T: } \quad \text { Clever! } \\
\text { identification? } \\
\text { WS: \# } \\
\text { S2: \#\# Pengenalan bu.. } \\
\text { T: } \\
\text { Identification means identifies } \\
\text { phenomenon to be described. } \\
\text { How about description? Do you } \\
\text { know what you can describe? } \\
\text { S17: Parts, qualities... } \\
\text { T: Exactly! What else? } \\
\text { S19: Character Mom! } \\
\text { T: Good, characteristics. }\end{array}$ \\
\hline & Making Descriptive Text & $\begin{array}{l}\text { T: Now, you make the } \\
\text { descriptive text which consists } \\
\text { of three paragraphs. They cover } \\
\text { identification and description. I } \\
\text { want you to emphasize the } \\
\text { content, grammar or structure } \\
\text { of writing, words or phrases, } \\
\text { spelling and using capital letters. }\end{array}$ \\
\hline
\end{tabular}




\begin{tabular}{|c|c|c|}
\hline & & $\begin{array}{l}\text { Do not forget to use the title for } \\
\text { your drafts. Do you understand? } \\
\text { Any questions? } \\
\text { S1: What's the content Mom? } \\
\text { T: The content of writing is } \\
\text { pesan yang terdapat dalam tulisan } \\
\text { itu. Is it clear or not? } \\
\text { S1: Clear, Mom. } \\
\text { T: Ok. Any other questions } \\
\text { or comments? } \\
\text { WS: \# } \\
\text { S11: Mom, Is it okay if I write } \\
\text { the sentences that have the } \\
\text { different ideas dari yang } \\
\text { sebelumnya saya tulis? } \\
\text { T: That's okay. You can add } \\
\text { the different ideas in your } \\
\text { writing to get more sentences. } \\
\text { Ok? } \\
\text { S11: Yes, I know Mom. }\end{array}$ \\
\hline $\begin{array}{l}\text { Post } \\
\text { Writing }\end{array}$ & $\begin{array}{l}\text { Displaying the group of } \\
\text { four (in pairs) }\end{array}$ & $\begin{array}{l}\text { T: In the previous meeting, you } \\
\text { have written the descriptive } \\
\text { text. Now make the group of } \\
\text { four (in the third meeting) or in } \\
\text { pairs (in the sixth meeting). } \\
\text { After that, tukar hasil tulisan } \\
\text { kalian dengan teman se grup } \\
\text { (pertemuan ketiga) atau pasangan } \\
\text { kalian (pertemuan keenam). Jangan } \\
\text { membawa hasil kerja kalian sendiri! } \\
\text { WS: Yes, Mom (making the } \\
\text { group of four or in pairs) }\end{array}$ \\
\hline & $\begin{array}{l}\text { Giving feedbacks to the } \\
\text { writings }\end{array}$ & $\begin{array}{l}\text { T: Now, give feedbacks atau } \\
\text { masukan atau saran for your } \\
\text { partner's works. Kalian bisa } \\
\text { melingkari kesalahan tulisan atau } \\
\text { kurang tepatnya tulisan teman }\end{array}$ \\
\hline
\end{tabular}




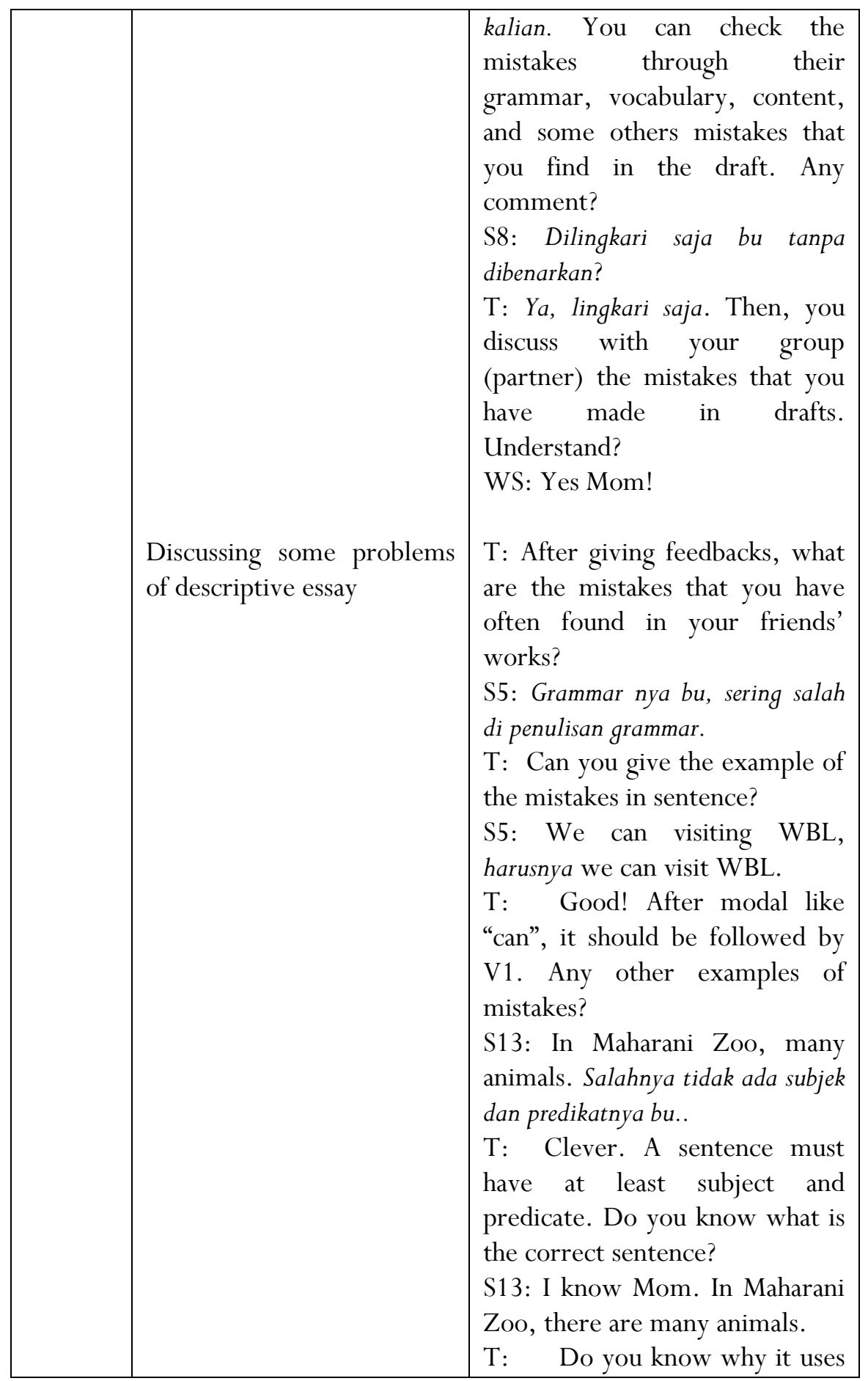




\begin{tabular}{|l|l|l|}
\hline \multirow{1}{*}{$\begin{array}{l}\text { Editing and re writing the } \\
\text { final drafts }\end{array}$} & $\begin{array}{l}\text { "are"? } \\
\text { S20: Karena banyak bu! } \\
\text { T: That's true. Karena hewan } \\
\text { yang disebutkan dalam jumlah } \\
\text { banyak atau jamak, kita } \\
\text { menggunakan are. } \\
\text { T: Next, you edit the drafts } \\
\text { based on some feedbacks from } \\
\text { your friends and the discussion } \\
\text { that we have made. } \\
\text { S19: What will we do after } \\
\text { editing our works, Mom? } \\
\text { T: Then, you can re write } \\
\text { your writing with the good } \\
\text { writing. Any comments? } \\
\text { S15: No, Mom. } \\
\text { T: Very good. Do it now and } \\
\text { get in hand your final writing to } \\
\text { me after you have finished my } \\
\text { instructions. } \\
\text { WS: Yes, Mom! }\end{array}$ \\
\hline
\end{tabular}

\section{Verification Data and Conclusion Drawing}

The third analysis activity was verification and conclusion drawing. The coding of data, for example (data condensation), leads to new ideas on what should go into a matrix (data display) entering the data requires further data condensation. As the matrix fills up, preliminary conclusions are drawn, but they lead to the decision (Miles et al., 2014: 32).

The data collected from observation in the form of checklist and fieldnotes through the implementation of "Put Yourself in the Picture" activity in teaching writing process were used to answer the first question. Then, the documents in the form of students' writing results were used to answer the second question. After that, the data were coded to decide the categorization data. This process was needed in order to make the researcher easier to take the next action. 
After having data categories, the next step was considered as data interpretation. The researcher was not only analyzing the data using the perspective but also correlating it with the previous theories. This statement was supported by Creswell (2012: 258) who points out that the qualitative inquirer interprets the data in view of this past research, showing how the findings may support or contradict prior studies, or both. He further explains that the qualitative researcher should suggest possible limitations or weaknesses of the study and makes recommendations for future research.

\section{RESULT AND DISCUSSION}

The focus of discussion was the implementation of "Put Yourself in the Picture" activity. The teacher presented a picture as the media and a teaching aid in the process of writing descriptive text. A descriptive text is a text that functions to describe a particular person, place, or thing (Wardiman et al., 2008: 46). The model of descriptive text is important for the students in junior high school. In accordance with this strategy, the students were encouraged to have the general image to communicate meaningfully.

Moreover, they would express their imagination freely as if they were in the pictures. It is the same as Lindstromberg (2004: 132) that tends to assign the students to imagine that they are involved in the pictures and represent those pictures into descriptive composition. Kinds of pictures used in this research were pictures of places. It is in line with Wright (1992: 86) who points out that pictures are very important in helping students to retell experiences or understand something since they represent place, object, people, etc.

In addition, this activity was helpful for the students in finding the ideas and recognizing the vocabulary items around their positions. This condition would stimulate them to construct various sentences related to the pictures and the topic discussed. It has the same core with Calhoun (1999: 68) in the use of pictures for students. Using pictures are easily understandable and accessible to our students helps them to be immediately and personally successful in visually reading the picture, shaking words out of the picture and generating the word list. 
Dealing with the writing process, the students implemented "Put Yourself in the Picture" activity in pre writing stage to help them in finding and developing their ideas. Then, after they had been given the explanation of descriptive text and its components to construct their first drafts in the writing stage, the students were led to give feedbacks to their friends' works in group and in pairs, edit, and re write their final drafts in the post writing stage.

In the prewriting stage, the students' activities were paying attention to the teacher's instruction, attaching the pictures on the provided sheets, making a list based on what they see in the pictures, and generating the ideas from listing stage to make meaningful sentences. All activities let the students to be involved actively of doing the tasks. It is appropriate to Wright stating the use of pictures can motivate the students and make him or her want to pay attention and want to take a part (Wright, 1992: 2).

The students were involved by placing themselves in the picture and they were led to make a list by answering leading questions "What can you see in the picture?" and "What do the people do in the picture?" In listing the ideas, the students got many vocabulary items to get words on paper. It is supported by Wingersky et al. (1999: 4) who state that prewriting is the planning to help us think, develop a topic, and get words on paper.

From their lists, the students were guided to make sentences based on their position in the picture. Subsequently, in giving instruction and explanation, the teacher used English and Indonesian. It was done in order to avoid misinterpretation and to facilitate the students in accomplishing the task more easily. Gebhard (2000: 79) states that the students have the tendency to start working a task sooner when it is clear to them.

In contrast, they were still confused in doing the tasks although the teacher had used English and Indonesian in order to get the clear instruction and explanation. To solve the problem, the teacher explained the steps in using the strategy slower and gave the students more time in listing the ideas and generating sentences before they were asked to write the drafts. 
Next, another problem that students faced was expressing the ideas in English. It was caused by inadequate number of dictionary. Only five students out of twenty students brought dictionaries. To solve this problem, teacher asked the students to borrow the dictionaries from the library or their friends to find the meanings of the words that they did not understand. After that, the teacher emphasized the importance of dictionary to help the students in finding the English version of some vocabulary items related to the topic discussed. For the reason, the students had to bring the dictionaries for the next meetings.

The second stage of writing processes was the writing stage. It was the process of drafting or getting ideas down. The students' activities in writing stage were paying attention to the teacher's explanation and putting down the ideas from the sentences and arranging them in a draft. Before asking the students to write their first drafts, the teacher gave a model paragraph then followed by the explanation. In this case, the teacher gave the example of descriptive text followed by the explanation and understanding of generic structures (identification and description) and language features (simple present tense, preposition, to be) of descriptive texts.

In writing the drafts, the teacher facilitated the students to explore their ideas freely without thinking greatly on grammar. This finding deals with the idea stated by Smalley, et al. (2001: 8) that in the drafting stage, the writer may not exceedingly concern with the grammatical form but the writer should focus more on finding the ideas to be put in the paper. However, the first results of the students showed that the students had difficulties in writing grammatically correct rules. They also used some misuse or confusing words in the sentences of their essays.

To solve these problems, in the following meetings, the teacher gave more detail explanation by giving feedbacks in doing conferences with the students applied in post writing stage. It is in line with Harmer (2004: 41) who claims that that one of the roles of teacher is to respond the students. The meaning of respond is reacting the content and construction of the tasks and making suggestions for their improvement. This finding showed that giving feedbacks could 
give positive impact on the students' drafts. At first, the students were reluctant to have discussion with the teacher, but later on they enjoyed the activities. Students can also participate actively in learning while getting responses from readers in non-threatening situation (Hyland, 2003: 199).

In post writing stage, the teacher instructed the students to revise or edit the draft of the writing. The students' activities in post writing stage were exchanging the draft with their friends, giving feedbacks or corrections for their partners' works, doing conference with the teacher, editing the draft based on some feedbacks from their friends and the teacher, and re writing their final writing. At first, the students were asked to do revising activity in groups (third meeting) and in pairs (sixth meeting) by exchanging their first drafts each others. Then, students were assigned to check their friends' drafts in the aspects of content, organization, vocabulary, and grammar. It is appropriate to Ploeger arguing when revising, we should focus on different aspects of writing, from how well the ideas are expressed and organized (the large perspective) to sentence structure (the narrow perspective) (Ploeger, 2000: 9).

Afterwards, the students were asked to circle the mistakes or errors of their friends' works based on their understanding without correcting them. After having discussion and doing conference, the owners of the writing sheets would edit the mistakes or errors by themselves. In relation to revise the writing, the teacher's explanation was not clear how to revise. The students still got difficulties in checking their friends' works. Because of the reason, the teacher provided the revising guidelines to help the students what points in the writing that should be revised. It is supported by Harmer (2004: 116) who states that the teacher needs to have guidance for the students so that they will what to look at when they read their classmates' work.

In the last meeting, they could progressively revise their friends' works in terms of the spelling, choice of words and grammar based on the teacher's guidance and revising guidelines. Nevertheless, these guidelines were only focused to revise the aspects of grammar and vocabulary. As the result, most of the students could write in the correct grammatical rules and choices of words although they were 
still in the simple ones, but some of the content of their writings were referred to another genre of the text, recount one.

To conclude, it can be assumed that Put Yourself in the Picture" activity can help the students in finding and developing their ideas. The students showed the progress of writing in the aspects of grammar and vocabulary. But, the students' understandings related to the generic structures of the descriptive text are still low. Some of the content of the students' texts were referred to the recount text instead of descriptive one. It is better if the teacher give more explanation or descriptions related to the aspects of the content of descriptive text and its components in doing conference with the students in post writing stage.

The data analysis selection of students' descriptive writing was obtained and described into five categories. They were (1) very good student's score category; (2) good student's score category; (3) fair student's score category; (4) poor student's score category; and (5) very poor student' score category. The students' results can be seen in the activities of listing the ideas, making or generating sentences, and from the final version of writing.

The students' final versions were included as final products of descriptive text. There were two products as the final writing. They were analyzed with the intention to know the students' learning progress by using Put Yourself in the Picture activity. The result of analysis of the students' final products was analyzed based on the scoring rubric of writing in the aspects of grammar, vocabulary, content, and organization. The students' final drafts were evaluated by using Analytical Scoring Rubric adapted from Cohen (1994: 328-329).

Dealing with the descriptions or analysis of the students' results, it can be found that the most problems that they faced were the use of correct grammatical rules, the effective choices of words, and the accurate content of the text. For the first results, the students could write many or some words in listing the ideas, but they still had difficulties in generating and developing the ideas into the sentences and drafts. Only few students wrote the text in good aspects.

Different from the previous results, the second ones showed that there were the better progresses in writing the text in the aspects 
of grammar and vocabulary. Most of the students wrote the vocabulary items as many as possible without being afraid of making mistakes and the students' texts were proper in grammatical rules although they were still in the simple form. Nevertheless, dealing with the content of the text, the student was lack of understanding the generic structures of descriptive text. Some of the students' texts wrote the continuous events intended as the generic structures of recount text. For the reason, the teacher should give more explanation how to write the correct generic structures of descriptive text intensively.

\section{CONCLUSION}

Based on findings on the previous chapter, it can be inferred that the writing process were included into three stages. They were pre writing, writing, and post writing stages. In pre writing stage, "Put Yourself in the Picture" activity was used to help the students in finding and developing their ideas. Then, after they had been given the explanation of descriptive text and its components to construct the drafts in the writing stage, the students were led to give feedbacks to their friends' works in group and in pairs, do conference with the teacher, edit, and re write their final drafts in the post writing stage.

The important points to be noticed in the implementation of "Put Yourself in the Picture" activity in those three stages were the teacher should explain the steps in using the activity slower in order to get the clear instruction and explanation and give the students more time in listing the ideas and generating sentences before they were asked to write the drafts. Then, dealing with expressing the ideas in English, it was important for the students to bring the dictionary in finding the meanings of the words that they did not understand.

In relation to revise the writing, the students were assigned to check their friends' drafts in the aspects of content, organization, vocabulary, and grammar. So, the teacher could provide the revising guidelines to help the students what points in the writing that should be revised. Furthermore, the students' learning writing progresses in terms of scores were described into five categories. They were (1) very good student's score category; (2) good student's score category; (3) fair student's score category; (4) poor student's score category; 
and (5) very poor student' score category. The students' results can be seen in the activities of listing the ideas, making or generating sentences, and from the final version of writing.

The students' final versions were included as final products of descriptive text. There were two products as the final writing. They were analyzed with the intention to know the students' learning progress by using Put Yourself in the Picture strategy. The results of analysis of the students' final products were analyzed and evaluated based on the scoring rubric of writing in the aspects of grammar, vocabulary, content, and organization adapted from Cohen (1994: 328-329).

Dealing with the descriptions or analysis of the first students' results, it can be found that the most problems that they faced were the use of correct grammatical rules, the effective choices of words, and the accurate content of the text. The students still had difficulties in developing the ideas into the sentences and drafts and using the correct grammatical rules. Only few students wrote the text in good aspects. Different from the previous results, the second ones showed that there were the better progresses in writing text in the aspects of grammar and vocabulary. Most of the students wrote the vocabulary items as many as possible without being afraid of making mistakes and the students' texts were proper in grammatical rules although they were still in the simple form.

Nevertheless, dealing with the content of the text, the student was lack of understanding the generic structures of descriptive text. Some of the students' texts wrote the continuous events intended as the generic structures of recount text. For the reason, the teacher should give more explanation how to write the correct generic structures of descriptive text intensively.

Based on the descriptions above, "Put Yourself in the Picture" activity gave some strength in teaching and learning descriptive texts. First, the students found that they were easy to get theictures. Second, it gave the students an easy way to find and generate the ideas by placing themselves in the pictures. Third, it encouraged the students to write without being afraid of making mistakes. Forth, it required students to work cooperatively in order to solve their problems by 
giving feedbacks, suggestions, or comments. At last, it encouraged positive teacher feedback rather than judgmental comments.

\section{SUGGESTIONS}

Based on the research findings and discussion, the researcher offers some suggestions. These suggestions are addressed to the teacher as a leader in the classroom and other researchers to improve the deeper results.

It is suggested that the teachers apply "Put Yourself in the Picture" activity to make the students feel enthusiastic and active in the process of writing. Because of the reason, they should focus on the following aspects: (1) the pictures should be adjusted based on the students' level and needs, (2) the explanation of the materials and the instructions in the worksheets should be presented clearly, and (3) the students should be grouped heterogeneously. Then, the teachers should consider writing as a process to be implemented in stages.

The other researchers, for those who are interested in applying "Put Yourself in the Picture" strategy in their research, are suggested that they develop the research of teaching writing descriptive texts or another genres of the texts suitable to be used in the different level of education. In addition, it is also suggested that they conduct the research of teaching writing using different genres for instance, narrative, directive, expository, or argumentative

\section{REFERENCES:}

Brown, H. D. (2001). Teaching by Principle: An Interactive Approach to Language Pedagogy. New York: Longman. - (2004). Language Assessment: Principles and Language Classroom Practices. White Plains, NY: Pearson Education

Calhoun, E. F. (1999). Teaching Beginning Reading and Writing with the Picture Word Inductive Model. Alexandria: ASCD. 
Creswell, J. W. (2012). Educational Research: Planning, Conducting, and Evaluating Quantitative and Qualitative Research [Fourth Edition]. Boston: Pearson Education, Inc.

Cohen, A. D. (1994). Assessing Language Ability in the Classroom [Second Edition]. Boston, MA: Heinle \& Heinle.

Gebhard, J. (2000). Teaching English as a Foreign or Second Language: A Teacher Self-development and Methodology Guide. Michigan: The University of Michigan Press.

Harmer, J. (1998). How to Teach English. New York: Longman. . (2004). How to Teach Writing. United Kingdom: Pearson Education Limited.

Heaton, J. B. (1991). Writing English Language Tests. New York: Longman Group.

Hyland, K. (2003). Second Language Writing. Cambridge: Cambridge University Press.

Linstromberg, S. (Ed.). (2004). Language Activities for Teenagers. Cambridge: Cambridge University Press.

Merriam, S. B. (2009). Qualitative Research: A Guide to Design and Implementation. San Fransisco: John Wiley \& Sons, Inc.

Miles, M. B., Huberman, A. M., \& Saldana, J. (2014). Qualitative Data Analysis: A Method Sourcebook [3rd Ed.]. Los Angeles: Sage Publication, Inc.

Ploeger, M. K. (2000). Simplified Paragraph Skill. Lincolnwood: NTC Publishing Group.

Smalley, R. L., Ruetten, M. K., \& Kozyev, J. R. (2001). Refining Composition Skills: Rhetoric and Grammar [5th Ed.]. Boston: Heinle and Heinle.

Sudarsono, S. (2001). A model of teaching analysis of process in writing class. Lingua Franca Vol. 2, June 2001. Jember: FKIPUNEJ.

Sulistiani, E.A. (2007). Employing Response Journal Writing Strategy to Improve Students' Writing Skills at the First Year of SMPN 8 Malang. Unpublished Thesis. Malang: State University of Malang.

Sundari, S. (2002). Improving second year students' writing skill through pictures at SLTPN 3 Jember. Lingua Franca, 3(6), 2332. Jember: FKIP-UNEJ. 
Wati, P. R. (2009). The Implementation of "Put Yourself in the Picture" Strategy to Improve EFL Writing Ability of the Second Year Students of MTs Muhammadiyah 1 Jombang. Unpublished Thesis. Malang: State University of Malang.

Wingersky, J., Boerner, J., \& Balogh, D. N. (1999). Writing Paragraphs and Essays: Integrating Reading, Writing, and Grammar Skills [Third Edition]. Belmont: Wordsworth Publishing Company.

Wiyanto, M. S. (2011). The Implementation of "Put Yourself in the Picture" Strategy to Improve Students Writing of Recount Text. Unpublished Thesis. Surabaya: State University of Surabaya.

Wright, A. (1992). Pictures for Language Learning. New York: Cambridge University Press.

Yin, R. K. (2011). Qualitative Research from Start to Finish. New York: The Guildford Press. 